\title{
Editorial
}

\section{The Journal of Morphological Sciences Presents the New Associate Editors}

\footnotetext{
${ }^{1}$ Department of Surgery and Anatomy, Faculdade de Medicina de Ribeirão Preto, Universidade de São Paulo, Ribeirão Preto, SP, Brazil
}

J Morphol Sci 2019;36:55-56.

The Journal of Morphological Sciences is still sometimes referred to as the Brazilian Journal of Morphological Sciences among the colleagues in the anatomical field of expertise, due to its direct link to the Brazilian Society of Anatomy. Historical facts about the creation of the journal and how it changed with time was recently published, ${ }^{1}$ and the name of the journal was changed to Journal of Morphological Sciences (in 2010) to broaden the readership and also to be an attractive journal for international contributors. Currently, more than $30 \%$ of the manuscripts published in the journal are from authors from outside of Brazil, and the journal will continue to work hard to expand its internationalization.

One challenge that the Journal of Morphological Sciences is facing is the variety of subjects of interest to our readers. We have detected three major areas of manuscripts submitted to our journal that need special attention from our editorial board to help speeding up the process of publication. Thus, three associate editors are reinforcing our editorial board to give particular attention to the manuscripts in their specific area of interest. They are highly qualified researchers in their fields, with national recognition and international prestige. These new associate editors are presented below.

\section{João Paulo Mardegan Issa, DDS, M.S., PhD (http:/|lattes.cnpq.br/9557307818304730)}

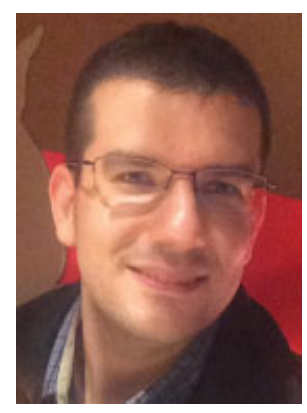

Graduated in dentistry from the University of São Paulo (2003), João Paulo Mardegan Issa holds a master’s degree in dentistry (oral rehabilitation) from the University of São Paulo (2006) and a PhD in sciences from the University of São Paulo (2007). He was a postdoc fellow with a FAPESP Scholarship in Brazil (2010) and abroad, at the Princess Margaret Hospital, University of Toronto (2013). He is currently an Associate Professor 1 in Anatomy at the Dental School of Ribeirão Preto, Universidade de São Paulo. He has experience in the area of bone repair and of regenerative medicine.

\section{Norberto Cysne Coimbra, MD, M.S., PhD (http:|/lattes.cnpq.br|7087724353350725)}

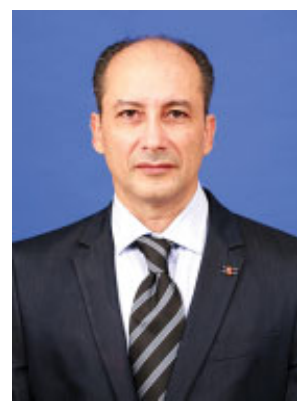

Norberto Cysne Coimbra is a medical doctor graduated at the Faculdade de Medicina of the Universidade Federal do Espírito Santo (1988), has a master's degree in neuropsychobiology from the Ribeirão Preto School of Philosophy, Sciences and Literature of the Universidade de São Paulo (1991), and PhD in morphology-cellular biology from the Ribeirão Preto Medical School of the Universidade de São Paulo (1995). He was a postdoc in the Pain Imaging Neuroscience (PaIN) Group of the Department of Physiology, Anatomy \& Genetics of the University of Oxford from 09/01/ 2006 to 30/06/2006, and in the Centre for Functional Magnetic Resonance Imaging of the Brain (FMRIB) of the Clinical

Copyright $\odot 2019$ by Thieme Revinter Publicações Ltda, Rio de Janeiro, Brazil

License terms 10.1055/s-0039-1692446. ISSN 2177-0298. 
Neurology Department of the University of Oxford (Oxford, England, United Kingdom), from 01/07/2006 to 08/01/2007. He is an Associate Professor (Level III) in the Department of Pharmacology of the Ribeirão Preto Medical School of the Universidade of São Paulo (2010), working mainly in the following subjects: neuroanatomy, neuropharmacology, psychopharmacology, neurotracing, fear defense, and behavior.

\section{Marco Aurélio Pereira Sampaio, DMV, M.S., PhD (http:|/lattes.cnpq.br|2974617010463918)}

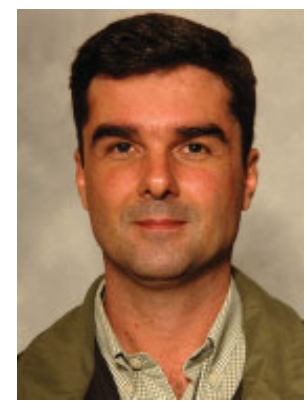

Marco Aurélio Pereira Sampaio holds a bachelor's degree in veterinary medicine from the Universidade Federal Fluminense (1985), a master's degree in morphology from the State University of Rio de Janeiro (1995), a PhD in morphology from the State University of Rio de Janeiro, with a PhD fellowship at the University of Tennessee. He is currently an Associate Professor at the Universidade Federal Fluminense, President of the World Association of Veterinary Anatomists, Member of the Subcommittee of Splanchnology of the
International Committee on Veterinary Gross Anatomical Nomenclature, Director of the Postgraduate Program in Pathophysiology and Surgical Sciences of the Universidade do Estado do Rio de Janeiro, and member of the editorial board of the journals Archives of Clinical Nephrology and Bulgarian Journal of Veterinary Medicine. Ad hoc reviewer of several international and national journals. He has experience in the area of morphology, with emphasis on plastination and comparative anatomy of the urogenital system, working mainly in the following subjects: animal anatomy, urology, surgical technique, experimental models in urology, teaching, and stereology.

Valéria Paula Sassoli Fazan MD, PhD, Editor-in-Chief Journal of Morphological Sciences

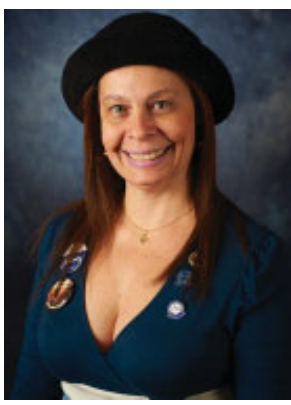

\section{Reference}

1 Rueff-Barroso et al. Profile Analysis of the Scientific Articles Published in the Journal of Morphological Sciences between 2000 and 2017: A Bibliometric Study. J Morphol Sci 2018;35 (04):255-260. Doi: 10.1055/s-0038-1676541 